\title{
Pårørende til selvmordstruede børn og unge. Et gruppetilbud til forældre - nogle resultater
}

\author{
Af Elene Fleischer og Anna Knudsen
}

\begin{abstract}
Artiklen er ikke videnskabeligt funderet, men tager udgangspunkt i praksis i en frivillig organisation, der har til formål at støtte og rådgive pårørende til selvmordstruede personer. Artiklen tager udgangspunkt i de tanker og bekymringer som forældrene har givet udtryk for undervejs i mødet med to fagprofessionelle rådgivere/gruppeledere.
\end{abstract}

\section{ABSTRACT}

I artiklen beskrives praksis og nogle af de overvejelser, der opstod som følge af dynamikken i de gennemførte samtalegrupper tilbudt forældre, der har en selvmordstruet søn eller datter. Grupperne har været forsøgt sammensat under hensyn til alder for at sikre en gensidig platform for forældrene. Artiklen beskriver forløbet af dynamik i gruppen fra det første møde med usikkerhed og anspændt stilhed til en mere afslappet og selvsikker stemning blandt forældrene. De føler sig i gruppeforløbet frie til at tale om deres følelser, og emner som usikkerhed, afmagt, angst bliver bragt frem. Også temaer som oversete søskende og situationens indflydelse på forældrenes parforhold er berørt. Psykoedukation indgår som et væsentligt element. Forfatterne går ind for at inkludere denne form for behandling som et element $i$ den offentlige forebyggelse af selvmord.

The survey deals with reflections generated due to the dynamics of groups comprising parents living with a suicidal child or adolescent. The groups have been composed with due respect to the age of the suicidal child/adolescent to secure a mutual platform for the parents. The article describes dynamics in the group from the first meeting with insecurity and tense quietness to a more relaxed and confident atmosphere among the parents. They feel free to speak about their emotions in the group and topics like insecurity, powerlessness, anxiety are brought forward. Other topics such as neglected siblings and the situation's impact on the parents' relationship are mentioned. Psycho-education is introduced. The authors advocate to include this kind of treatment as an element in the public suicide prevention.
Forældrenes udsagn er blevet genstand for "fortolkning" af gruppelederne, der har anvendt egne faglige erfaringer og kompetencer fra deres hverdag i psykiatrien og fra det selvmordsforebyggende arbejde generelt. Tolkningerne er ikke bundet af nogen teoristyring, men har åbent forholdt sig til de givne udsagn.

Rammen for gruppesamtalerne er fire grundregler, som er beskrevet i artiklen: "St $\varnothing$ tte til forældre til selvmordstruede sønner og d $\varnothing$ tre - metodeovervejelser" (2012). Disse er anvendt med det formål at styrke de pårørendes tryghed. Formen har medført at tanker og følelser som den pårørende har opfattet som forbudte, har kunnet siges åbent og reflekteres.

\section{Når verden vælter}

\section{Ambivalens}

Der kommer forskellige følelser frem gennem forl $\varnothing$ bet. Også stærke følelser, som ikke umiddelbart er genkendelige for forældrene selv. En mor sætter ord på nogle af dem: "Jeg hader min søn!" En anden siger: "Bare jeg kunne sende hende (datteren) ud på en øde ø et stykke tid."

Forældrene har svært ved at håndtere deres egen sårbarhed og mistilliden til barnet, som de ikke længere tør stole på. Tiltroen til egen forældreevne er også ramt. "Min skyldfølelse var stor, og jeg var rigtig meget $i$ tvivl om, hvordan jeg skulle agere over for hende. Jeg må lære at nyde mine andre børn, og når den yngste vokser op-huske at give slip på hende i tide og derved lære hende at tage ansvar for sit liv. Jeg skal lære at nyde min mand og vores voksenforhold vel vidende, at jeg er god nok. Der er stadig tilbagefald $i$ min manglende tro på mig selv som mor, kvinde, menneske, men det går den rigtige vej nu." Der tales meget om den evige angst for, at det kan ske igen, og at døden denne gang kan blive en realitet. Som en mor siger: "Jeg er splittet mellem frygten for, at han skal begå selumord, og lettelsen, hvis han gjorde det." En anden mor sætter ord på sin afmagt: "Jeg kan intet stille op, hvis han virkelig vil dø." Enkelte af de andre mødre nikker genkendende til denne rekapitulation på afmagten.

Interaktionen mellem forældrene fylder ligeledes. Her er især forskellige synsvinkler på krav kontra omsorg for den selvmordstruede $\varsigma \varnothing$ n eller datter. Noget, som forældrene har svært ved at blive enige om. Der tales om kvinder og mænds forskellige reaktionsmåde; at mænd som regel er mindre emotionelt funderet end kvinder og har sværere ved at sætte ord på følelser.

\section{Bliv ikke aedt op indefra}

Erfaringerne fra grupperne viser, at der er k $\varnothing$ nsbestemte forskelle i forældrenes reaktioner på deres barns selvmordsfors $\varnothing \mathrm{g}$ (Garde, K. \& Gerlach, J. (2006)). "Som mand har jeg haft en anden maide at tackle det på. Jeg har først ikke villet snakke om det, og har måske gået med (det) for længe. Min kone har villet snakke meget om det, hvor jeg følte det fyldte for meget og lukkede af, hvilket ikke gjorde situationen bedre mellem os."

Deres usikkerhed og angst kan medføre, at de uden støttende og rådgivende hjælp fastlåses i fortidens angst, og denne angst skaber frygt for fremtiden. En frygt, der ofte blokerer for deres barns bestræbelser på at blive set i en ligeværdig her og nusituation.

Forældrenes egenomsorg kan blive mindre, ligesom omsorgen for den anden forælder kan glemmes. Nogle fædre påtager sig ansvar for at håndtere moderens afmagt og tilsidesætter derved egne behov. Hos andre fædre ser det ud til at afmagten kan danne grobund for frustrationer, der belaster forældrenes parforhold. Der er blandt forældrene et behov for at få st $\varnothing$ tte til at finde plads til forskellighed og retten til at have enetid/vennetid midt i kaos. Nogle af forældrene tilsidesætter eller glemmer, at der skal være tid til vedligeholdelse 
af parforholdet og kontakten til de $\varnothing$ vrige børn i familien. Den tid der er til rådighed deles mellem den selvmordstruede søn eller datter og til det at passe arbejdet. Alt andet ser ud til at få mindre betydning og tildeles mindre tid.

Forældrepar har reflekteret over de belastninger deres barns selvmordsfors $\varnothing \mathrm{g}$ påfører ægteskabet. I flere tilfælde har netop fokus på parforholdet og st $\varnothing$ tten i gruppen medført, at parret ikke er gået fra hinanden i tiden efter deres barns selvmordsfors $\varnothing g$. En far skriver efter at have afsluttet et forl $\varnothing \mathrm{b}$ i NEFOS: "Til pårørende vil jeg give dette råd: Snak om det, men lad det ikke fylde hele Jeres tilværelse, for så bliver I ædt op indefra, og når den selumordstruede er $i$ balance igen, vil I ikke være de hele mennesker, han eller hun kendte."

\section{At se det $i$ øjnene}

Et af de sværeste emner er om der ligger en psykisk lidelse til grund for selvmordsfors $\varnothing$ get. For nogle bliver det en realitet, hvilket en mor udtrykker således: "At have en søn, der har en psykiatrisk lidelse er svært at leve med. Men at spekulere over de mange problemer gennem de seneste ar forud for selumordsforsøget er også vanskeligt. Jeg er nået frem til at mit fokus må være at arbejde for at min søn overlever - og ikke meget andet." Hertil siger en af de andre: "Vi må acceptere, at hvis et af vore børn vil dø, så kan vi ikke som forældre stille noget op." Hun fortsætter efter en kort pause: "... og kunne de så ikke tage at lykkes med det, så jeg skal forholde mig til resultatet og ikke til uvisheden.'

Disse udtryk for afmagt og håbløshed følger forældrene gennem hele processen. Samtidig sker der en udvikling undervejs, idet der i begyndelsen er megen gråd, ensomhedsfølelse og tavshed. "Som mand har jeg haft en anden måde at tackle det på. Jeg har forst ikke villet snakke om det, og har måske gået med (det) for længe. Min kone har villet snakke meget om det, hvor jeg følte, det fyldte for meget og lukkede af, hvilket ikke gjorde situationen bedre mellem os." Gruppeprocessen udvikler sig for den enkelte, der både oplever at kunne stå ved egne følelser og tanker og være i stand til at spejle sig i de andre deltageres oplevelser gennem den kommunikative proces - en udvikling, der mindsker den eksistentielle, den emotionelle og den sociale ensomhed (Fleischer 2009).

\section{Usynlige søskende}

Behandlernes og forældrenes fokus er rettet mod den unge, der har fors $\varnothing g t$ selvmord. Dermed er der en risiko for at søskendes reaktioner på selvmordsforsøget glemmes eller overses. Gruppelederne sætter fokus på søskende og stiller åbne spørgsmål som: "Hvordan er selvmordsforsøget blevet oplevet af søskende?" Det er de færreste forældre, der er bevidste om usynligg $\varnothing$ relsen af s $\varnothing$ skende. De bliver ofte først opmærksomme på det, når en søskende reagerer anderledes

\section{En selvmordshandling - utallige berørte}

\section{Har du oplevet selvmordsforsøg eller trussel om selvmord?}

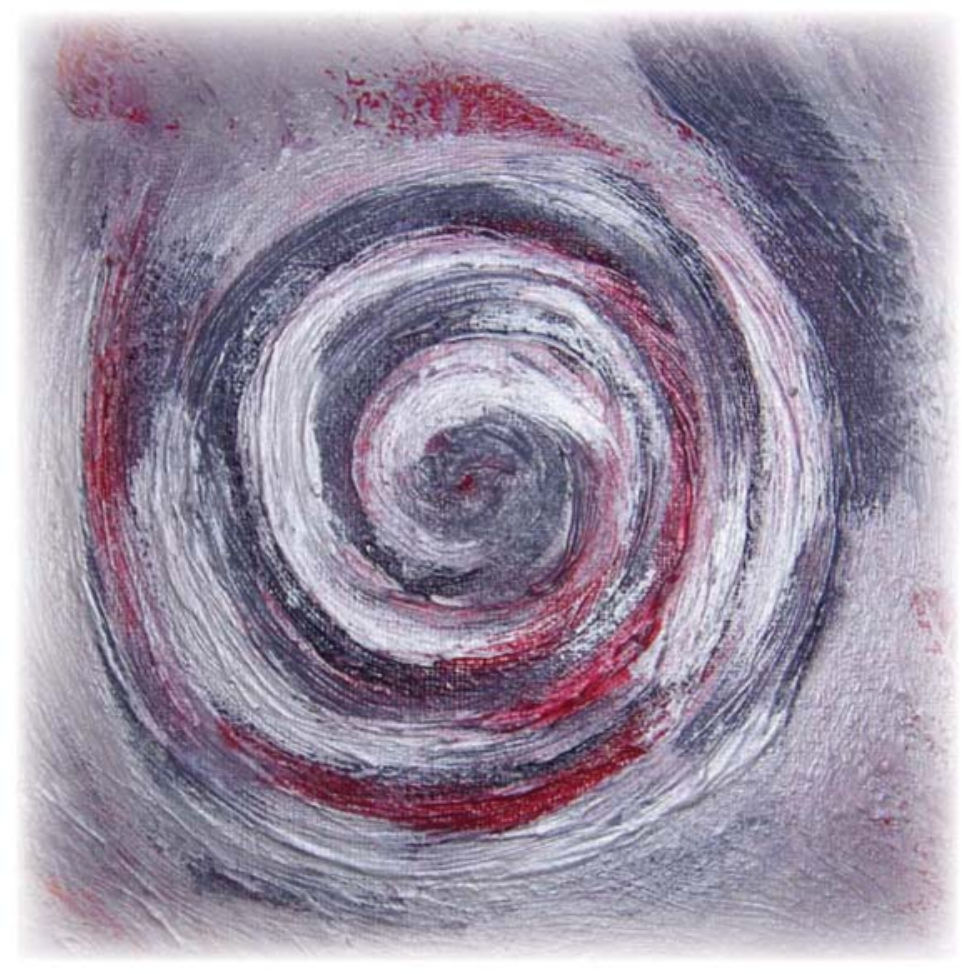

\section{Er du pårørende eller nær ven? Så er dette et tilbud til dig!}


end forventet. Fx hvis den ellers så "gode" datter pludselig agerer vredt og bliver krævende: "Vi har aldrig haft problemer med hende før, men nu er hun blevet lige så krævende som sin bror (der har forsøgt selvmord)."

Flere forældre erkender at søskende har valgt den selvmordstruede bror eller søster fra i vrede. De oplever en tristhed og bekymring ved at se det tidligere gode forhold mellem søskende er forsvundet eller blevet massivt belastet.

Et begreb, der undervejs dukker op som synonym for usynlige søskende, er

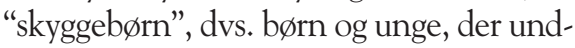
går at skabe problemer for de i forvejen bekymrede forældre. Nogle bliver i skyggen, mens andre træder ud af den i vrede og frustration og kræver den samme opmærksomhed, som forældrene giver den selvmordstruede (Søndergaard 2008).

En del af de forældre, der har deltaget i samtalegrupper, giver udtryk for en frustration i forhold til de offentlige behandlingstilbud. De siger at de forventes at tage over når den selvmordstruede udskrives fra sygehuset, selvom de som forældre ikke oplever at s $\varnothing$ nnen eller datteren er udenfor selvmordsfare. De oplever at der lægges et pres på dem. De oplever ofte at $150 \%$ stillen op for deres barn tilsyneladende ikke er tilstrækkeligt. Samtidigt har den enkelte forælder heller ikke haft ressourcer til at sige nej eller stille krav på sønnens eller datterens vegne. Derfor står han/hun med afmagt, stress og belastninger, der i flere tilfælde resulterer $\mathrm{i}$ at de som forældre må sygemelde sig i en periode.

\section{Det, der braender $p a ̊$}

Følgende temaer er på forskellig vis blevet fremsat undervejs i et eller flere gruppeforløb. Når de dukkede op her og nu, er de gjort til genstand for psykoedukation:

Køn og alder - forskellige reaktionsmønstre ved belastninger, kriser og sorg er et centralt element, netop fordi far, mor og søskende opdager at de reagerer forskelligt (Garde \& Gerlach 2006).

Søskende, uanset om disse er ældre eller yngre, reagerer ofte, når forældrene ensidigt har fokus på den selvmordstruede.
Hvorledes disse såkaldte skyggebørn reagerer, er drøftet ud fra hvorledes barnet tidligere reagerede ved belastninger (Søndergaard 2008).

At opleve sig anderledes eller forkert medfører at isolation let bliver en strategi til mestring af belastningerne. De forskellige former for ensomhed - den eksistentielle, emotionelle og sociale ensomhed - er blevet illustreret, og artikler om ensomhed er udleveret (Fleischer 2009).

En af de teoretiske tilnærminge der er gjort massivt brug af, er den kognitive behandlingsmodel, der er yderst velegnet i forhold til at håndtere angst (Oestrich 2000). Fortid/nutid/fremtid som styrende elementer i den enkeltes måde at forholde sig til selvmordshandlingen på (forældre kontra den unge selvmordstruede) er fremhævet flere gange, og forældrene oplever en forståelse når det beskrives voksnes og børns forskelligheder i forhold til nutid (som her og nu) kontra fremtiden. Automatiske - kontra alternative - tankers indvirkning på vores kommunikation og handlinger er anskueliggjort.

Følelserne, som angst, frustration, vrede, afmagt, skyld, medansvar, uvished, at være en dårlig forælder, fylder meget de første gange gruppen er samlet og aff $\varnothing \mathrm{der}$ megen gråd og fortvivlelse. Sammenhængen mellem afmagt, manglende kontrol og forældreansvar kontra omsorg, herunder kontrol/overgreb, er ligeledes et tilbagevendende dilemma.

I psykoedukationen (den anden halvdel af gruppesessionen) er de nyeste forskningsteorier om bl.a. depression, borderline-diagnose, overforbrug af alkohol og stoffer og co-alkoholisme samt behandlingsmulighederne blevet drøftet. Foræeldreansvar kontra behandleransvar af den selvmordstruede afklares eksplicit. Recidivrisikoen, hvad siger forskningen og hvorledes lever vi som forældre med angsten? fylder meget, men som regel er forældrene først klar til at få fakta efter fjerde eller femte gang gruppen er samlet. Der er brugt en del tid på at udrede og forklare forskelle på selvmordsfors $\varnothing \mathrm{g}$ og selvmutilerende handlinger, ligesom forskellen på teenageadfærd og selvmordsadfærd er drøftet flere gange (Spaten 2010).

Synligg $\varnothing$ relsen af kommunikationsvanskeligheder, utydelig kommunikation og tavshed er nogle af de elementer, som især fædrene oplever givende at fă drøftet (Fleischer 2000).

\section{Opfølgning}

I slutningen af 2011 viser erfaringerne, at forældre til børn med $\mathrm{fx}$ borderlinediagnose og affektive lidelser, der kan medf $\varnothing$ re tilbagevendende suicidale tanker og adfærd, ser ud til at være specielt belastede. Er der en rolig periode i den selvmordstruedes sygdom, medfører det over tid for nogle af forældrene at de "falder tilbage" til tidligere omgangsformer og kommunikationsm $\varnothing$ nstre. Det er hverken befordrende for deres barn eller for dem selv. Forældre efterspurgte "genopfriskning af redskaber", og i september 2011 blev der etableret en 'brush upgruppe', målrettet de forældre der havde afsluttet et gruppeforl $\varnothing b$ 1-1 1/2 år forinden. Som en af fædrene udtrykte det: "få et spark til igen at gøre det mere rigtige."

\section{Diskussion}

I gruppesamtalens intervention er det rollen og individet som mor eller far der styrkes og st $\varnothing$ ttes. Synligg $\varnothing$ relsen giver måske også en sikkerhed i forældrerollen, som de selv og måske også andre har sat spørgsmålstegn ved, da søn/datter udf $\varnothing$ rte en selvmordshandling. Et godt og stabilt netværk kan formodentlig være til lige så god hjælp for pårørende. Dog er det vores opfattelse at netværk også udtrættes, og forældrene ikke synes det er rigtigt at belaste venskaber og familienetværket med den angst og usikkerhed der udspiller sig i deres tanker og følelser.

Udfordringen er at den selvmordstruede efter specifik målrettet selvmordsforebyggende behandling fortsat er en del af et familienetværk. Tilliden er som følge af selvmordsfors $\varnothing$ get påvirket negativt. Angsten for nye selvmordshandlinger er latent til stede. Rådvildhed lammer positive kommunikative $m \varnothing$ nstre og 
mestringsstrategier. Vi står med ubesvarede spørgsmål: Øges risikoen for recidiv, når forældrene er utrygge og usikre?

Det ser ud til at søskende, der i kortere eller længere perioder oplever utryghed og usikkerhed i familien, og samtidigt også oplever at forældrenes opmærksomhed primært er på den selvmordstruede, kan have en $\varnothing$ get risiko for mistrivsel. Der forefindes så vidt vides ikke forskning, der har haft disse temaer som fokus. Det kan selvfølgelig diskuteres, om det at have selvmordsfors $\varnothing \mathrm{g}$ som en familiær belastning er anderledes end at have en kræftsyg søster eller bror, eller have et familiemedlem der gentagne gange indlægges som følge af psykiatrisk lidelse. Det ved vi ikke noget om.

Mange af forældrene har ved henvendelsen givet udtryk for at de har brug for et netværk der kender problemerne og den følelsesmæssige belastning det er at være pårørende og stå i afmagt og usikkerhed med døden som en mulighed. Der er meget der tyder på at de får et sådant netværk gennem denne form for intervention.

\section{Et samfundsansvar}

Denne form for behandlingstilbud kan efter vores mening ydes ved at fagpersoner der repræsenterer forskellige fag og behandlingsinstanser samarbejder tværsektorielt og tværfagligt med optimal respekt for hinandens faglighed.

Det kan selvfølgelig diskuteres om et interventionstilbud til forældre, der ikke er syge, skal findes inden for det sundhedsfaglige behandlingstilbud. Et tilbud til pårørende til selvmordstruede $b \varnothing r$ efter vores opfattelse ses som en investering i forebyggelse, der på længere sigt måske mindsker de $\varnothing$ konomiske byrder der følger med når mennesker udvikler stress eller depression som følge af belastninger der ikke er afhjulpet.

Noget ganske andet er at forældrene er vigtige samarbejdspartnere, og de forventes at stille op når den selvmordstruede har endt sin behandling, eller når den selvmordstruede nægter at tage imod en foreslået behandling. Forældre er forældre uanset barnets alder. Det er et skisma, for samtidig med at den selv- mordstruede unge over 18 år har ret til tavshed om behandlingen, er der hos forældre et behov for at kende til de lægelige anbefalinger for ikke at gå imod dem. Forældrene er generelt bange for at de kan sige eller gøre noget som får sønnen eller datteren til at gentage forsøget, og at dette resulterer i selvmord. Derfor finder vi det vigtigt med en grundig orientering af forældrene, i det mindste på et overordnet niveau.

\section{Og en forebyggende indsats}

Det er forfatternes opfattelse at et tilbud om gruppesamtale/terapi og rådgivning til forældre til selvmordstruede unge har en positiv effekt. Forældrene giver udtryk for at de kommer styrket ud af behandlingsforløbet når de rette fysiske og mentale rammer er til stede. De oplever, at de ikke står alene i situationen, men at der er andre forældre med præcis de samme bekymringer. De lærer at føle sig 'gode nok' både som forældre og som ægtefæller, og de magter at rumme de mange forskelligartede følelser, der opstår i kølvandet på deres barns selvmordsfors $\varnothing \mathrm{g}$ : angst, frustration, vrede, afmagt, skyld, medansvar og uvished. Samtidigt udvikler de andre kommunikations- og mestringsstrategier, hvor de præsenterede og indlærte alternative tanker afprøves og måske også mere permanent anvendes. Det kan selvfølgelig diskuteres om den samme bedring ikke finder sted som et resultat af sønnens og datterens behandling, eller at tiden som sådan også forbedrer forældrenes mentale sundhed.

\section{Fremadrettet}

I nærværende artikel har vi frit tolket nogle af de udsagn forældre til selvmordstruede s $\varnothing$ nner og døtre er fremkommet med under gruppesamtalerne. Der er alene tolket og beskrevet ud fra de erfaringer der er hentet fra praksis.

Et igangværende forskningsprojekt vurderet af Syddansk Strategiråd for Psykiatrisk Forskning: Selumordsforebyggende indsats: Støtte og rådgiuning til forældre, søskende og andre pårørende efter selumordsfors $\emptyset$ g (2012-2013), inddrager både kvalitative og kvantitative variable, der kan dokumentere og beskrive deltagernes oplevede effekt af tilbuddet om gruppesamtaler i NEFOS.

Etiske aspekter: Der er optimalt hensyntagen til at forældre er belastede og i krise. Ved svære psykologiske belastninger henvises til relevant lægelig eller psykologisk behandling. Alle pårørende er blevet spurgt om vi må bruge deres anonymiserede udsagn.

Interessekonflikter: Ingen

$\varnothing$ konomisk støtte: Projektet er støttet af: TrygFonden, Odense Kommune, Socialministeriet m.fl.

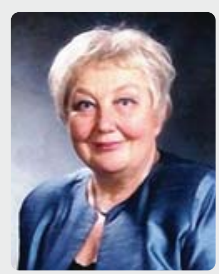

Elene Fleischer, ph.d. er daglig leder i Forskning og Forebyggelse i Odense og formand for landsforeningen NEFOS, Netværket for Selvmordsramte, www.NEFOS.dk. Hun var 1998-1999 ansat i lektorat ved Troms $\varnothing$ Høiskole og 2000-2009 som specialkonsulent ved Nordnorsk psykiatriske forskningscenter (NNPF) Troms $\varnothing$. Hun var i 20002009 ansat ved Center for Selvmordsforebyggelse, Region Nordjylland, som projektleder på indsatsprojektet: Forebyggelse af ældre menneskers selvmord.

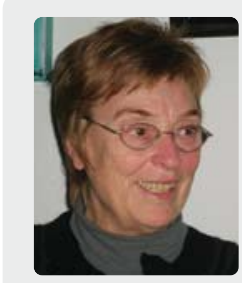

Anna F. Knudsen er psykiater og leder af Klinik og Kompetencecenter for selvmordsforebyggelse, Psykiatrien i Region Syddanmark. Hun var 19932001 ansat som adm. overlæge i Psykiatrien i Troms $\varnothing$.

\section{Referencer}

Fleischer, E. (2009). Ensomheden - selvmordets f $\varnothing$ lgesvend. Månedsskrift for praktisk lægegerning. S. $421-410$, nr. 4 .

Fleischer, E. (2000). Den talende Tavshed. Selvmord og selvmordsfors $\phi \mathrm{g}$ som talehandling. (Oprindelig Ph.d.-afhandling 1997) DK: Odense Universitetsforlag.

Garde, K. \& Gerlach, J. (2006). Psykiske sygdomme - forskellen mellem mænd og kvinder. København: Psykiatri Fondens Forlag.

Oestrich, T.H. (2000). Tankens kraft - kognitiv terapi i klinisk praksis. Dansk Psykologisk Forlag.

Spaten, O.M. (2010). Unges selvopfattelse k $\phi$ n, udvikling, forældre og identitet. Aalborg: Institut for Kommunikation og Psykologi, AAU Søndergaard, P.S. (2008). Skrig \& fred - om selvmordsfors $\varnothing \mathrm{g}$ blandt unge. Aarhus: Turbine. 